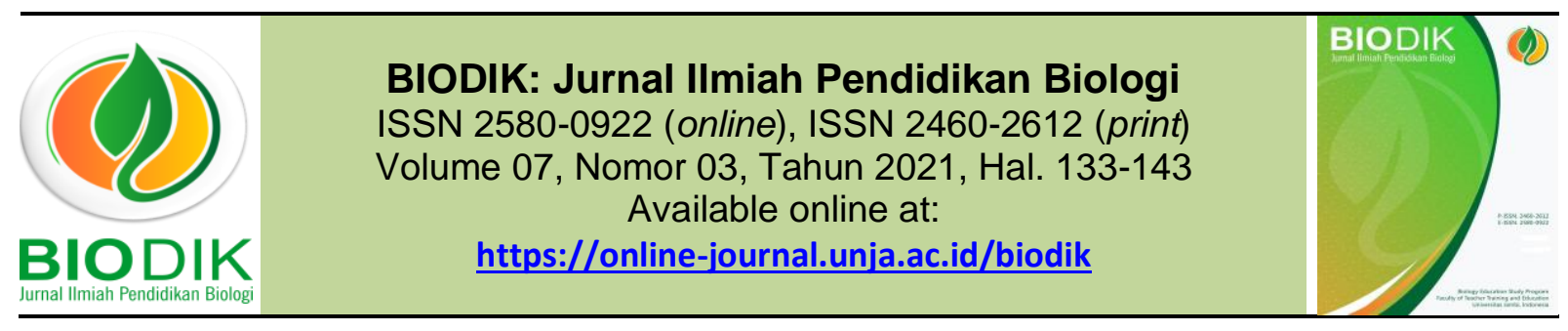

Research Article

\title{
Pengembangan Bahan Ajar Ekosistem Berbasis Potensi Lokal Di Maluku
}

\author{
(Development of Local Potential-Based Ecosystem Teaching Materials in Maluku)
}

Junardin M Masihu1* ${ }^{\text {, Sartje Augustyn² }}$

\author{
${ }^{1 *}$ Program Studi Pendidikan Biologi, Jurusan MIPA, STKIP Gotong Royong Masohi \\ 2 SD Kristen Haruru \\ JIn. Transeram Belakang Negeri Haruru, Kota Masohi, Kabupaten Maluku Tengah 97514 \\ *Corresponding author: junardinmasihu31@yahoo.com
}

\begin{tabular}{|c|c|}
\hline Informasi Artikel & ABSTRACT \\
\hline $\begin{array}{l}\text { Submit: } 18-06-2021 \\
\text { Diterima: } 30-08-2021 \\
\text { Dipublikasikan: } 29-09-2021\end{array}$ & $\begin{array}{l}\text { One way to use the environment is to examine the local potential that exists in } \\
\text { the student's environment. The selection of the development of teaching } \\
\text { materials based on local potential is in accordance with biological characteristics, } \\
\text { especially those that utilize living things and their parts. The purpose of this } \\
\text { research is to develop teaching materials based on local potential in Maluku. The } \\
\text { research method uses the R\&D method with the ADDIE model. The data } \\
\text { collection technique used is data regarding the need for learning resources in the } \\
\text { form of local wisdom-based learning modules in Maluku collected through } 2013 \\
\text { curriculum analysis. The instrument used is a questionnaire. Based on the } \\
\text { analysis conducted on research and development data, it shows that teaching } \\
\text { materials based on Maluku local wisdom are feasible to be used as a source of } \\
\text { learning in schools. Local wisdom-based teaching materials developed can be } \\
\text { used as teaching materials that can increase students'knowledge of the material } \\
\text { being studied. The feasibility of the developed teaching materials can be } \\
\text { measured using indicators of the validity of teaching materials, practicality of } \\
\text { teaching materials, and effectiveness of teaching materials. The study results } \\
\text { showed a significant change between the pre-test and post-test. It can be } \\
\text { concluded that teaching materials based on Maluku local wisdom are very } \\
\text { feasible to be used in learning. } \\
\text { Key words: Teaching Materials, Local Potential }\end{array}$ \\
\hline Penerbit & ABSTRAK \\
\hline $\begin{array}{l}\text { Program Studi Pendidikan Biologi } \\
\text { FKIP Universitas Islam Madura, } \\
\text { Jawa Timur- Indonesia }\end{array}$ & $\begin{array}{l}\text { Salah satu pemanfataan lingkungan adalah dengan mengkaji potensi lokal yang } \\
\text { ada di lingkungan peserta didik. Pemilihan pengembangan bahan ajar berbasis } \\
\text { potensi lokal sangat sesuai dengan karakteristik biologi khususnya yang } \\
\text { memanfaatkan mahluk hidup maupun bagiannya. Tujuan penelitian ini adalah } \\
\text { mengembangkan bahan ajar ekosisitem berbasis potensi lokal di Maluku. } \\
\text { Metode penelitian menggunakan metode R\&D dengan model ADDIE. Teknik } \\
\text { pengumpulan data yang dilakukan adalah data mengenai kebutuhan sumber } \\
\text { belajar dalam bentuk modul pembelajaran berbasis kearifan lokal di Maluku } \\
\text { dikumpulkan melalui analisis kurikulum 2013. Instrumen yang digunakan adalah } \\
\text { angket. Berdasarkan analisis yang dilakukan terhadap data hasil penelitian dan } \\
\text { pengembangan menunjukkan bahwa bahan ajar berbasis kearifan lokal Maluku } \\
\text { layak untuk digunakan sebagai salah satu sumber belajar di sekolah. Bahan ajar } \\
\text { berbasis kearifan lokal yang dikembangkan dapat digunakan sebagai bahan ajar }\end{array}$ \\
\hline
\end{tabular}


yang dapat meningkatkan pengetahuan peserta didik terhadap materi yang dipelajari. Kelayakan dari bahan ajar yang dikembangkan dapat diukur dengan menggunakan indikator kevalidan bahan ajar, kepraktisan bahan ajar, dan keefektifan bahan ajar. Hasil belajar menunjukkan perubahan yang signifikan antara pre test dan post test. Dapat disimpulkan bahwa bahan ajar berbasis kearifan lokal Maluku sangat layak untuk digunakan dalam pembelajaran. Kata kunci: Bahan Ajar, Potensi Lokal

This BIODIK : Jurnal IImiah Pendidikan Biologi is licensed under a CC BY-NC-SA (Creative Commons Attribution-ShareAlike 4.0 International License)

\section{PENDAHULUAN}

Pembelajaran biologi sebagai salah satu bagian dari pendidikan memiliki potensi yang besar dalam memanfaatkan lingkungan sebagai sumber belajar (Talakua, 2020). Salah satu pemanfataan lingkungan adalah dengan mengkaji potensi lokal yang ada di lingkungan peserta didik. Pemilihan pengembangan bahan ajar berbasis potensi lokal sangat sesuai dengan karakteristik biologi khususnya yang memanfaatkan mahluk hidup maupun bagiannya. Selain itu bahan ajar ini akan merangsang peserta didik untuk tanggap dengan berbagai potensi lokal yang bisa dikembangkan, dan ini akan membuat peserta didik lebih kritis dan lebih mudah menerapkan apa yang sudah dipelajarinya ke lingkungan. Menindaklanjuti hal itu pengembangan bahan ajar sangat penting untuk dilakukan terutama bahan ajar yang menekankan pada proses, sehingga pembelajaran peserta didik menjadi lebih bermakana (Laksana, 2015)

Selanjutnya menurut Nurhidayati, dkk (2016), realitanya masih banyak guru yang menggunakan bahan ajar yang sudah jadi seperti Buku Tematik yang telah disediakan oleh pemerintah atau LKS yang merupakan hasil dari suatu penerbit yang mungkin tidak sesuai dengan lingkungan di mana siswa tersebut belajar. Kondisi ini tentunya dapat mempersulit peserta didik dalam memahami materi yang seharusnya mereka kuasai. Bahan ajar cetak kurang mengedepankan unsur lingkungan dan budaya lokal masyarakat setempat.

Materi yang diintegrasikan kedalam modul berbasis kearifan local ini adalah Ekosistem. Hal tersebut disebabkan materi ekosistem yang selama ini dipelajari jarang menggunakan kearifan local didaerah peserta didik sebagai contoh dalam meninjau materi tersebut lebih jauh. Ekosistem merupakan salah satu materi esensial dalam Biologi yang membahas adanya interaksi antara makhluk hidup dengan lingkungannya. Lingkungan yang spesifik dan kondisional akan memberikan ragam persoalan IImu Pengetahuan Alam dan memberikan relevansi antara kajian teoritis dan aplikasi. Serta akan melibatkan kemampuan kognitif dan psikomotoris peserta didik, sehingga pemahaman konsep yang didapatkan akan lebih mengena (melekat) dibandingkan dengan penjelasan melalui ceramah (Akbar, 2013)

Maluku termasuk bagian timur Indonesia yang memiliki banyak sumber daya serta potensi diantaranya sumber daya alam seperti hamparan pantai-pantai yang sangat indah dan alami, selain sumber daya alamnya yang terkenal (Persada,2018). Keanekaragaman ekosistem di Maluku memiliki keunikan untuk dikembangkan menjadi bahan ajar pada materi ekosistem. Selain itu belum tersedianya bahan ajar yang memanfaatkan berbagai potensi lokal, padahal lingkungan kita sangat beragam dan kaya akan berbagai potensi. Dengan memanfaatkan berbagai potensi yang ada di lingkungan sekitar tentunya peserta didik tidak hanya memahami bahan ajar secara teoritis tetapi juga lebih aplikatif dan lebih peduli pada lingkungan sekitar (Arsyad, 2015). 
Wawancara secara langsung dengan pendidik bidang studi biologi mengenai pembelajaran biologi yang menghubungkan kondisi lingkungan sekolah, tempat tinggal, serta sosial budaya belum pernah dilakukan, bahkan pengembangan bahan ajar yang didalamnya memuat kearifan lokal pun belum pernah dilakukan, padahal dengan adanya pembelajaran yang menyesuaikan kondisi lingkungan peserta didik akan mendukung peserta didik. Penelitian dan pengembangan bahan sebenarnya sudah banyak dilakukan namun penelitian pengembangan bahan ajar berbasis kearifan lokal khususnya di daerah Maluku pada mata pelajaran biologi khususnya ekosistem belum dilakukan.

Berdasarkan uraian pentingnya bahan ajar terutama yang memanfaatkan berbagai potensi lokal, maka dalam penelitian ini dilakukan pengembangan bahan ajar ekosistem berbasis potensi lokal di Maluku. Berdasarkan latar belakang maka rumusan masalah dalam penelitian ini yakni Bagaimanakah potensi lokal di Maluku yang bisa dikembangkan menjadi bahan ajar ekosistem? Adapun tujuan penelitian ini adalah untuk mengidentifikasi berbagai potensi lokal yang bisa dijadikan bahan ajar ekosistem. Bahan ajar ekosistem perlu dikembangkan untuk mengeksplorasi lebih jauh tentang berbagai potensi lokal yang ada di lingkungan sekitar, karena daerah kita kaya akan keanekaragaman mahluk hidup dan potensipotensi yang dapat dijadikan sumber belajar.

\section{METODE PENELITIAN}

Bahan ajar berbasis kearifan lokal ini dikembangkan dengan model ADDIE. Model ini terdiri atas lima langkah, yaitu: analyze, design, development, implementation, dan evaluation (Tinja, dkk. 2017).

a. Pada tahap analisis (analyze), meliputi kegiatan pemilihan jenis bahan ajar, analisis kebutuhan belajar dan Kompetensi Inti (KI) dan Kompetensi Dasar (KD) pada kelas X SMA yang dapat diintegrasikan dengan unsur kearifan lokal Masyarakat Maluku sesuai dengan kerangka implementasi kurikulum 2013.

b. Pada tahapan perancangan (design), dilakukan dengan kerangka acuan sebagai berikut. (1) unsurunsur kearifal lokal yang relevan diintegrasikan dalam bahan ajar untuk siswa kelas X SMA, (2) Nilai unsur-unsur kearifal lokal diintegrasikan ke dalam materi yang relevan dengan kurikulum 2013.

c. Pada tahapan pengembangan (development), dilakukan dengan menyusun bahan ajar yang terintegrasi ke dalam tema-tema pembelajaran di kelas X SMA.

d. Pada tahapan implementasi (implementation), kegiatan dilakukan uji coba terbatas bahan ajar berbasis kearifal lokal Masyarakat Maluku kepada guru dan siswa.

e. Pada tahapan evaluasi (evaluation), dilakukan evaluasi bahan ajar yang dihasilkan berdasarkan hasil ujicoba. Lebih lanju tahapanya dapat dilihat pada gambar 1 dibawah ini. 


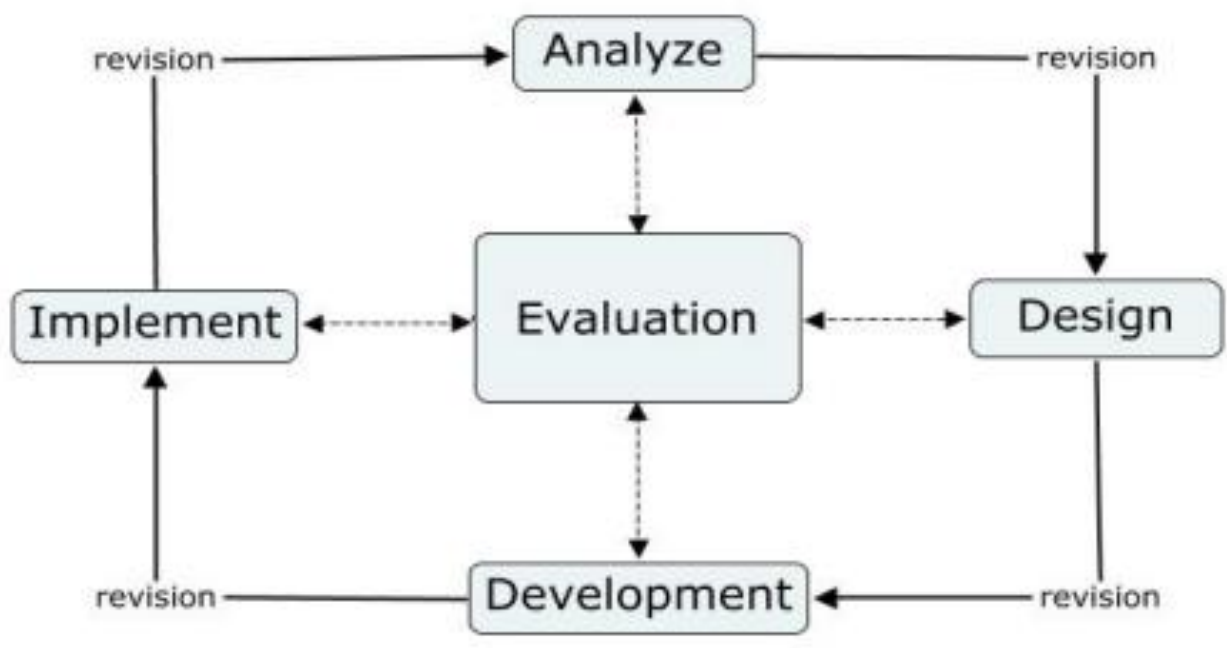

Gambar 1. langkah-langkah model ADDIE.

Penelitian ini dilakukan di Kabupaten Maluku Tengah Provinsi Maluku. Subjek dalam penelitian ini adalah kurikulum 2013 kelas X serta guru Biologi dan siswa kelas X SMA Kristen Haruru di Kecamatan Amahai Kabupaten Maluku Tengah. Penelitian ini terbatas sampai dihasilkannya produk akhir bahan ajar dan belum melakukan pengujian ke lapangan untuk menguji secara metodologis penggunaan bahan ajar berbasis kearifan lokal Masyarakat Maluku terhadap hasil belajar siswa. Teknik pengumpulan data yang dilakukan adalah sebagai berikut:

1. Data mengenai kebutuhan sumber belajar dalam bentuk modul pembelajaran berbasis kearifan lokal di Maluku dikumpulkan melalui analisis kurikulum 2013 dan melalui angket. Analisis kebutuhan dilakukan bersama antara peneliti dengan guru-guru SMA Kristen Haruru yang tergabung dalam Kelompok Kerja Guru (KKG) Kecamatan Amahai.

2. Data mengenai potensi sekolah atau wilayah dan karakteristiknya yang relevan dengan kebutuhan sumber belajar belajar berbasis kearifan lokal dalam bentuk bahan ajar pembelajaran dari tiap sekolah dikumpulkan melalui: (a) Angket (diberikan ke guru-guru SMA yang tergabung dalam KKG Kecamatan Amahai; (b) Investigasi/observasi langsung ke lokasi untuk memperoleh informasi mengenai karakteristik kearifan lokal Masyasrakat Maluku sebagai konten dan konteks sumber belajar ekosistem pada kelas X SMA.

3. Data mengenai kualitas bahan ajar pembelajaran biologi berbasis kearifan lokal dilihat dari isi, penyajian dan kebahasaan diperoleh dari guru dan siswa dalam ujicoba terbatas menggunakan angket yang telah disusun. Data diambil setelah guru dan siswa menggunakan bahan ajar tersebut dalam kegiatan pembelajaran.

\section{HASIL PENELITIAN DAN PEMBAHASAN}

Pengembangan bahan ajar ekosistem berbasis kearifan lokal di Maluku dilakukan berdasarkan langkah model pengembangan pada ADDIE (Analysis, Design, Development, Implementation and Evaluation). Tahapan tersebut secara garis besar dapat digambarkan sebagai berikut:

\section{A. Tahap Analisis (Analysis)}

Analisis Kebutuhan Dari hasil wawancara dan observasi terhadap pembelajaran biologi kelas $X$ SMA Kristen Haruru pada semester genap tahun 2020/2021 sebanyak 70\% peserta didik belum 
mencapai nilai baik. Pada tahap analisis kebutuhan peneliti melihat beberapa kesulitan yang dialami peserta didik baik dalam kegiatan pembelajaran maupun pada saat kegiatan praktikum berlangsung. Peserta didik mengalami kesulitan ketika memahami konsep yang diberikan guru dan pembelajaran yang dilakukan tanpa dikaitkan dengan lingkungan sekitar. Dari observasi diperoleh informasi bahwa pembelajaran yang dilakukan hanya bersifat teacher center. Hal tersebut dikarenakan guru belum bisa mengembangkan media pembelajaran yang mampu mendukung proses pembelajaranya. Lebih lanjut pengembangan bahan ajar yang didalamnya memuat kearifan lokal pun belum pernah dilakukan, padahal dengan adanya pembelajaran yang menyesuaikan kondisi lingkungan peserta didik akan mendukung peserta didik.

Berdasarkan analisis yang telah dilakukan maka diperlukan pengembangan bahan ajar ekosistem berbasis kearifan lokal di Maluku yang dapat dengan mudah diakses oleh peserta didik. Dasar pengembangan bahan ajar ekosistem berbasis kearifan lokal di Maluku dikembangkan agar dapat bahan ajar yang dilengkapi dengan ilustrasi yang mewakili jenis ataupun bentuk kearifan lokal yang sesuai dengan lingkungan/alam di Maluku. Selanjutnya pembelajaran pada materi ekosistem tersebut dapat mudah dicerna peserta didik karena bahan ajar tersebut mampu mengidentifikasi kearifan lokal yang dikenal peserta didik.

\section{B. Tahap Desain (Design)}

Pembuatan produk direncanakan berlangsung selama empat bulan namun dalam pelaksanaanya membutuhkan waktu selama enam bulan yang meliputi pengumpulan data, pembuatan produk, analisis produk dan evaluasi produk yang dimulai dari bulan Januari 2021 hingga bulan Maret 2021 dilanjutkan dengan kegiatan validasi yang dimulai dari bulan April hingga bulan Juni 2021. Pengumpulan data diperoleh dari buku-buku, dokumentasi gambar yang relevan, dan produk yang sebelumnya telah dikembangkan sebagai refrensi.Selanjutnya produk dikembangkan dari data yang telah terkumpul serta dikembangkan berdasarkan storyboard produk yang telah didesain. Setelah produk dikembangkan dievaluasi berdasarkan pada saran dan pendapat validator media dan materi serta persepsi guru dan peserta didik. Adapun proses desain bahan ajar yang dikembangkan adalah:

1. Mengumpulkan Referensi Materi

Kegiatan yang dilakukan oleh peneliti pada tahap ini yaitu mengumpulkan referensi yang akan dijadikan sumber pembuatan bahan ajar ekosistem berbasis kearifan lokal di Maluku, selain itu peneliti memilih beberapa contoh media berbasis kearifan lokal yang akan dimuat pada bahan ajar yang akan dikembangkan. Pada kegiatan ini peneliti menggunakan beberapa buku rujukan tentang media dan sumber dari internet dan diskusi dengan beberapa pemuka atau tokoh masyarakat di Maluku mengenai kearifan lokal yang telah dikembangkan.

\section{Penyusunan Teks}

Pada kegiatan ini peneliti menyusun teks sesuai dengan KBBI. Sedangkan untuk penyusunan kalimat, peneliti menyusun kalimat tidak baku agar bahan ajar ini tidak kaku ketika dibaca namun peneliti tetap memperhatikan kaidah bahasa yang harus digunakan untuk tidak mengurangi nilai-nilai pendidikan didalamnya.

\section{Pemilihan Bahan Ajar}

Pemilihan bahan ajar berupa modul ekosistem berbasis kearifan lokal di Maluku didasarkan pada hasil tahap analisis bahwa belum ada modul yang gunakan oleh guru media sebelumnya. Peserta didik 
juga perlu dibekali informasi tentang kearifan lokal yang ada dimaluku sehingga mampu mengaitkannya dengan materi ekosistem.

\section{Desain Bahan Ajar}

Pada tahap mendesain modul ini peneliti menggunakan software Corel Draw dan Microsoft Word. Tahap awal desain modul terdiri dari halaman judul, daftar isi, kata pegantar, dan deskripsi mata kuliah, Tampilan pelengkap awal modul ini dapat disajikan oleh peneliti sebagai berikut:

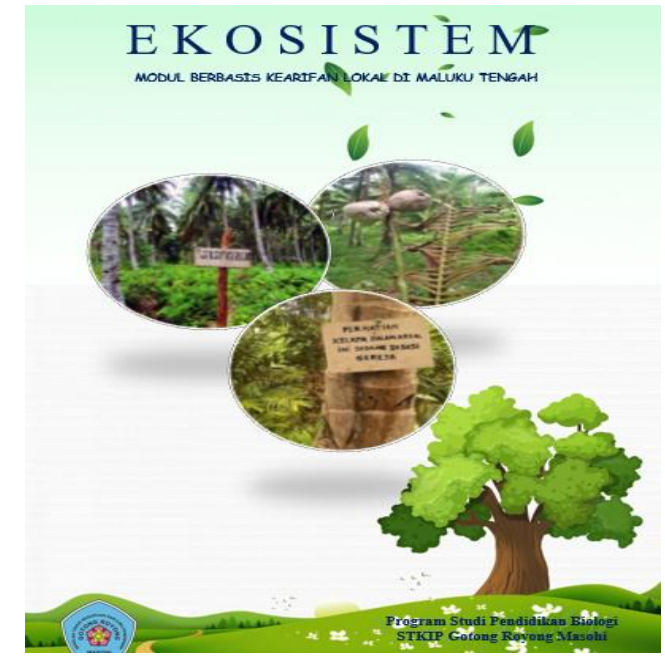

Gambar 2. Tampilan Depan Modul

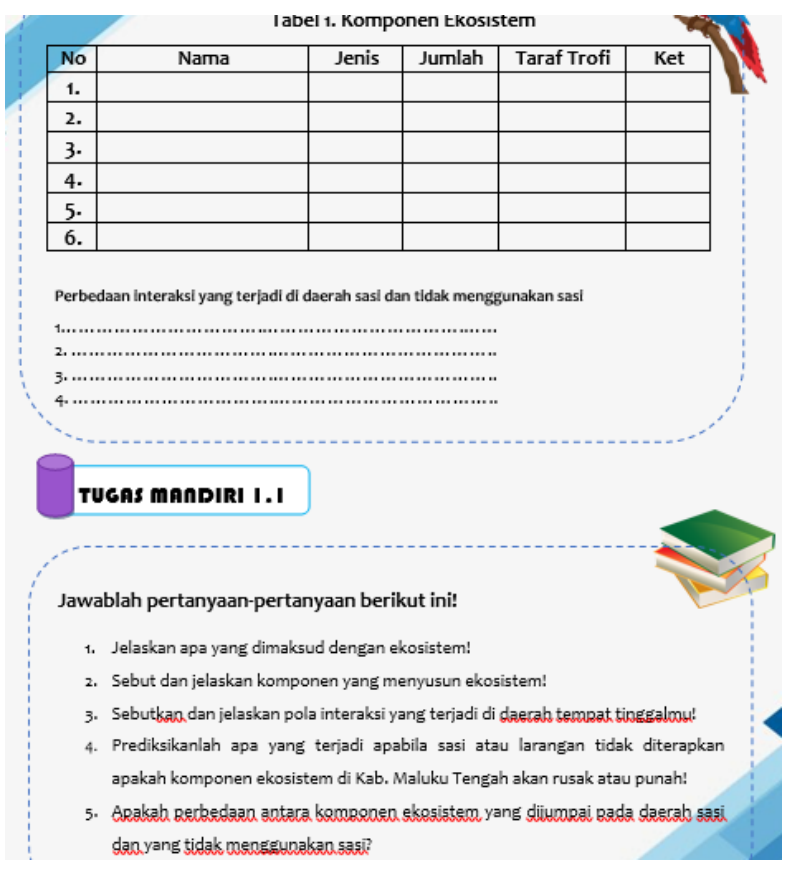

Gambar 3. Tampilan Isi Modul

\section{Tahap Pengembangan}

Tahap pengembangan ini merupakan tahapan terakhir pada pengembangan modul media pembelajaran ekosistem berbasis kearifan lokal di Maluku ini. Pada tahap ini merupakan tahap untuk mewujudkan desain modul yang telah direncanakan pada tahap perancangan menjadi sebuah produk bahan ajar. Perancangan modul ini berupa foto dalam bentuk JPEG yang kemudian dimasukkan ke 
dalam microsoft word untuk kemudian dicetak dalam bentuk booklet. Langkah selanjutnya yaitu modul ekosistem berbasis kearifan lokal di Maluku di validasi oleh para ahli.

Dalam tahap validasi bahan ajar disebarkan ke para ahli yang terdiri dari 3 orang dosen. Validasi bahan ajar media pembelajaran merupakan suatu proses penilaian yang dilakukan pada sebuah produk/media untuk mengetahui produk/media tersebut valid atau tidak, sehingga dapat diketahui kelayakan media pembelajaran tersebut untuk digunakan pada proses pembelajaran atau tidak. Validasi ini merupakan salah satu cara untuk mengevaluasi dan menyempurnakan hasil pengembangan modul media pembelajaran yang dilakukan oleh peneliti. Untuk penilaian validasi peneliti telah memilih 3 orang dosen, yaitu: Febiayu Aloatuan., M.Pd, Sovian Sesca Elly., M.Pd dan Kevin Andrea Tamaela.,M.Pd. Aspek yang divalidasi meliputi materi, kebahasaan, penyajian dan tampilan menyeluruh. Berikut peneliti sajikan rekapitulasi data penilaian hasil validasi dari para ahli pada tabel 1.

Tabel 1. Rekapitulasi Kevalidan Produk Bahan Ajar

\begin{tabular}{cccc}
\hline Validator & Skor yang dicapai (\%) & $\begin{array}{c}\text { Skor maksimal yang } \\
\text { diharapkan }\end{array}$ & Kualifikasi \\
\hline Ahli Materi & 82 & 100 & Sangat Valid \\
\hline Ahli Desain & 75 & & Valid \\
\hline Ahli Bahasa & 90 & & Sangat Valid \\
\hline
\end{tabular}

Validasi ahli bertujuan untuk mengetahui kevalidan dan kelayakan produk yang dihasilkan berdasarkan pendapat para ahli (Prabowo, 2016:1090-1097). Validasi ahli materi dilakukan untuk menilai keseuaian materi dengan standar kompetesi dan kompetensi dasar yang terdapat dalam silabus serta sesuai dengan karakteristik peserta didik. Selain itu, ahli materi juga menilai tata bahasa yang digunakan dalam produk bahan ajar yang dikembangkan. Validasi dilakukan terhadap modul yang dikembangkan dengan berpedoman pada instrumen yang ada. Dalam instrumen penilaian validasi materi terhadap produk bahan ajar, terdapat 29 butir penilaian untuk modul yang dibuat. Masing-masing item dengan skor minimal 1 dan skor maksimal 4.

Berdasarkan penilaian yang dilakukan validasi ahli terhadap modul yang dikembangkan, total skor yang diberikan mencapai 105. Berdasarkan total skor tersebut jika dipresentasikan mencapai presentasi $82 \%$. Presentasi tersebut jika dikonversikan ke dalam tabel konversi yang ada berada pada kategori sangat valid. Sementara penilaian ahli Bahasa terhadap buku modul ekosistem berbasis kearifan lokal di Maluku mencapai total skor 117 . Total skor tersebut mencapai persentase $90 \%$ dan berada pada kategori sangat valid.

Validasi ahli desain dilakukan untuk menilai tampilan dari buku siswa dan buku panduan guru. Dalam instrument penilaian ahli desain terdapat 15 butir indikator atau aspek yang dinilai terhadap modul yang dikembangkan. Skor maskimal untuk masing-masing butir indikator adalah 4. Dengan demikian, skor maksimal untuk dalah 60 . Berdasarkan penilaian yang dilakukan oleh ahli desain, total skor untuk modul mencapai 45 . Total skor tesebut jika dipresentasikan mencapai persentase $75 \%$. Persentase tersebut jika dikonversikan menurut tabel konversi yang tersedia berada pada kategori valid.

\section{Tahap Implementasi}

Kegiatan dilakukan uji coba terbatas bahan ajar berbasis kearifal lokal Masyarakat Maluku kepada guru dan siswa. Bahan ajar yang telah dikembangkan diujicobakan kepada siswa kelas X SMA Kristen Haruru. Hasil pengembangan bahan ajar berbasis kearifan lokal di Maluku yang dibuat dalam 
bentuk modul kemudian dinilai oleh siswa dalam bentuk pemberian anget kepada guru dan siswa serta tes untuk menilai hasil belajar siswa setelah menggunakan modul ini sebagai bahan ajarnya. Hasil yang diperoleh adalah sebagai berikut:

1. Persepsi guru terhadap bahan ajar berbasis kearifan local yang dikembangkan dengan menyebarkan angket kepada 2 orang guru biologi di SMA Kristen Haruru mendapatkan skor 122 dengan presentase $89 \%$.

2. Persepsi peserta didik pada bahan ajar berbasis kearifan lokal yang dikembangkan dengan menyebarkan angket kepada 32 orang peserta didik terdiri dari 8 orang pada kelompok kecil dan 24 orang pada kelompok besar. Nilai persepsi pada kelompok kecil meraih skor 399 dengan persentase sebesar $89 \%$ dan pada kelompok besar meraih skor 1164 dengan persentase $86 \%$.

\section{E. Tahap Evaluasi}

Tahap evaluasi dilakukan untuk mengetahui efektifitas modul berbasis kearifan lokal Maluku yang dikembangkan. Uji coba lapangan dilakukan untuk mengetahui tingkat kepraktisan dari produk bahan ajar yang dikembangkan. Uji coba lapangan dilakukan sebanya tiga kali yaitu uji coba perorangan, uji coba kelompok kecil dan uji coba lapangan. Uji coba kelompok kecil dilakukan kepada tiga orang peserta didik, uji coba kelompok kecil dilakukan kepada enam orang peserta didik, dan uji coba lapangan dilakukan kepada 20 orang peserta didik. Dalam setiap uji coba dilakukan pengisian angket untuk menilai keterbacaan dari produk bahan ajar yang dikembangkan. Angket juga diisi oleh guru untuk menilai bahan ajar yang telah dikembangkan.

Dari uji coba yang dilakukan, dalam uji coba perorangan, persentase kepraktisan dari bahan ajar peserta didik mencapai $87 \%$ dengan kualifikasi sangat praktis. Uji coba kelompok kecil mencapai persentase kepraktisan sebesar $87 \%$ dengan kualifikasi sangat praktis. Uji coba lapangan mencapai persentase kepraktisan sebesar $87 \%$ dengan kualifikasi $87 \%$. Sementara untuk respon guru pada bahan ajar mencapai persentase $92 \%$ dengan kualifikasi sangat praktis,

Selanjutnya dilakukan tes hasil belajar peserta didik untuk menilai keefektifan penggunaan bahan ajar yang dikembangkan. Hasil belajar siswa dilakukan melaui pre test dan post test. Pre test dilakukan sebelum pembelajaran dengan menggunakan produk bahan ajar, sedangkan post test dilakukan setelah pembelajaran menggunakan produk bahan ajar. Penilaian hasil belajar dilakukan untuk mengukur tingkat pemahaman materi ekosistem yang telah dipelajari siswa dalam produk bahan ajar. Hal ini bertujuan untuk mengetahui apakah penggunaan produk bahan ajar berbasis kearifan lokal di Maluku yang ada dapat meningkatkan pengetahuan peserta didik dalam mempelajari materi ekosistem.

Hasil penilaian pre test dibandingkan dengan hasil penilaian post test. Hal tersebut dilakukan untuk mengetahui apakah ada perbedaan hasil sebelum menggunakan produk bahan ajar dengan setelah menggunakan produk bahan ajar yang ada. Pada pre test yang dilakukan, rata-rata perolehan nilai peserta didik mencapai 62 . Dari 24 orang peserta didik, 22 peserta didik semuanya memperoleh nilai di bawah KKM. Setelah dilaksanakan pembelajaran dengan menggunakan produk bahan ajar berbasis kearifan lokal terjadi peningkatan pemahaman peserta didik terhadap materi yang dipelajari. Hal tersebut diketahui dari post test yang dilakukan setelah kegiatan pembelajaran berlangsung. Perolehan nilai siswa mencapai rata-rata 85. Dari 24 orang siswa yang mengikuti post test, 20 orang siswa mencapai ketuntasan belajar.Berdasarkan hasil tersebut menunjukan bahwa perubahan yang signifikan terhadap penggunaan produk bahan ajar yang digunakan. 
Berdasarkan hasil terasebut dapat dikatakan bahwa penggunaan bahan ajar berbasis keatifan lokal sangat efektif. Hal tersebut sesuai dengan pendapat Suraida (2013) bahan pengembangan bahan ajar dikatakan efektif jika tingkat ketuntasan hasil tes sesudah lebih besar daripada hasil tes sebelumnya. Berdasarkan hasil penelitian, diperoleh bahwa ada banyak sekali potensi local yang bisa dijadikan bahan ajar terutama pada materi ekosistem. Melalui sumber belajar tersebut peserta didik dapat mengenal lingkungnnya dan dapat meningkatkan pemahaman langsung terhadap konsep. Hal tersebut sejalan dengan pendapat Fahrianoor (2013) yang menjelaskan bahwa sumber belajar yang ideal harus memenuhi beberapa kriteria diantaranya Potensi lokal yang berada di lingkungan bertujuan untuk mengajak peserta didik untuk bersentuhan langsung dengan objek materi biologi dalam bentuk aktivitas dan eksperimen.

\section{SIMPULAN}

Berdasarkan analisis yang dilakukan terhadap data hasil penelitian dan pengembangan menunjukkan bahwa bahan ajar berbasis kearifan lokal Maluku layak untuk digunakan sebagai salah satu sumber belajar di sekolah. Bahan ajar berbasis kearifan lokal yang dikembangkan dapat digunakan sebagai bahan ajar yang dapat meningkatkan pengetahuan peserta didik terhadap materi yang dipelajari. Kelayakan dari bahan ajar yang dikembangkan dapat diukur dengan menggunakan indikator kevalidan bahan ajar, kepraktisan bahan ajar, dan keefektifan bahan ajar. Berdasarkan total skor tersebut jika dipresentasikan mencapai presentasi $82 \%$. Presentasi tersebut jika dikonversikan ke dalam tabel konversi yang ada berada pada kategori sangat valid. Sementara penilaian ahli Bahasa terhadap buku modul ekosistem berbasis kearifan lokal di Maluku mencapai total skor 117. Total skor tersebut mencapai persentase $90 \%$ dan berada pada kategori sangat valid. Validasi ahli desain dilakukan untuk menilai tampilan dari buku siswa dan buku panduan guru. Dalam instrument penilaian ahli desain terdapat 15 butir indikator atau aspek yang dinilai terhadap modul yang dikembangkan. Persentase tersebut juga menunjukkan bahan ajar berbasis kearifan lokal Maluku yang dikembangkan sangat praktis untuk digunkan dalam pembelajaran. Sementara dari aspek keefektifan menunjukkan bahwa persentase keaktifan siswa selama pembelajaran mencapai rata-rata $80 \%$ dan berada pada pada kategori sangat aktif. Hasil belajar menunjukkan perubahan yang signifikan antara pre test dan post tes. Oleh karena itu, dapat disimpulkan bahan ajar berbasis kearifan lokal Maluku sangat layak untuk digunakan dalam pembelajaran. Berdasarkan hasil penelitian dan pengembangan yang dilakukan, guru dapat menggunakan bahan ajar berbasis kearifan lokal sebagai salah satu sumber yang dapat digunakan dalam pembelajaran. Untuk mengatasi kesulitan bahan ajar yang tidak memadai, guru hendaknya mengembangkan bahan ajar yang sesuai dengan karakteristik peserta didik dan kondisi tempat guru mengajar. Dengan tersedianya bahan ajar yang memadai diharapkan pembelajaran dapat berjalan secara efisien dan efektif dan pada akhirnya mampu meningkatkan hasil belajar peserta didik

\section{UCAPAN TERIMAKASIH}

1. Menteri Pendidikan, Kebudayaan, Riset, dan Teknologi, Bapak Nadiem Makarim yang telah membantu dalam mendanai penelitian dosen ini.

2. Kalsum Sehulawano, S.Pdl., M.Pd selaku Ketua STKIP Gotong Royong Masohi yang telah memberi motivasi dan dorongan dalam penelitian ini.

3. Kepala Sekolah SMA Kristen Haruru Kabupaten Maluku Tengah yang telah membantu dan berkontribusi dalam pelaksanaan penelitian ini. 
4. Marlen Sahureka, S.Si., M.Sc selaku Ketua LPPM yang telah berkontribusi dalam membantu pelaksanaan penelitian ini.

\section{RUJUKAN}

Akbar, S.(2013). Instrumen Perangkat Pembelajaran. Bandung: PT Remaja Rosdakarya.

Ariyani, D.Y. \& Wangid, M.N. (2016). Pengembangan bahan ajar tematik integratif berbasis nilai karakter peduli lingkungan dan tanggung jawab. Jurnal Pendidikan Karakter, 6 (1), 116-129.

Arsyad, A. (2015). Media Pembelajaran. Jakarta: PT Raja Grafindo Persada

Duncan, M. (2014). How the Cultural Contexts of Urban Teaching Affect Novice Science Educators: Implications for School Leaders. International Journal of Educational Leadership Preparation, 9 (1), 1-17.

Fahrianoor, Windari, T., Taharuddin, Ruslimar, \& Maryono. (2013). The practice of local wisdom of Dayak people inforest conservation in south kalimantan. Indonesian Journal of Wetlands Environmental Management. (1), 38-46

Hartono, W dan Noto, M.S. (2017). Pengembangan Modul Berbasis Penemuan terbimbing Untuk Meningkatkan Kemampuan Matematis Pada Perkuliahan Kalkulus Integral. JNPM (Jurnal Nasional Pendidikan Matematika) Vol. 1 No. 2 Hal. 320-333.

Khanifah, S., Pukan, K. K., \& Sukaesih, S. (2012). Pemanfaatan Lingkungan Sekolah sebagai Sumber Belajar untuk Meningkatkan Hasil Belajar Siswa. Unnes Journal of Biology Education, 1 (1): 82-89.

Laksana, D.N L. \& Wawe, F. (2015). Penggunaan Media Berbasis Budaya Lokal Dalam Pembelajaran IPA untuk Meningkatkan Aktivitas dan Pemahaman Konsep IPA Siswa Sekolah Dasar. Jurnal IImiah Pendidikan Citra Bakti, 2 (1), 27-37

Laksana, D.N L. \& Wawe, F. (2015). Penggunaan Media Berbasis Budaya Lokal Dalam Pembelajaran IPA untuk Meningkatkan Aktivitas dan Pemahaman Konsep IPA Siswa Sekolah Dasar. Jurnal IImiah Pendidikan Citra Bakti, 2 (1), 27-37.

Mulyasa. (2013). Pengembangan dan Implementasi Kurikulum 2013. Bandung : PT Remaja Rosdakarya. Nurhidayati, S. dan Khaeruman (2016). Pengembangan bahan ajar berbasis STAD dipadu Inkuiri terbimbing pada materi homologi. Penelitian Internal. FPMIPA. IKIP Mataram.

Northcote, M., Kilgour, P., Reynaud, D., \& Fitzsimmons, P. (2014). Engaging in Deep Cultural Learning through the Intersection of Multiple Contexts. Australian Journal of Teacher Education. 39 (10), 4763

Persada, N.P.R., Mangunjaya, F.M., \& Tobing, I.S.L. (2018). Sasi sebagai Budaya Konservasi Sumber Daya Alam di Kepulauan Maluku. Jurnal dan Budaya IImu, Vol. 41, No.59, Juli 2018.

Purnomo, H. \& Wilujeng, I. (2016). Pengembangan bahan ajar dan instrumen penilaian IPA tema Indahnya Negeriku penyempurnaan buku guru dan siswa kurikulum 2013. Jurnal Prima Edukasia, 4 (1), 67-78

Sarah dan Mariono. (2014). Keefektifan Pembelajaran Berbasis Potensi Lokal dalam Pembelajaran Fisika SMA dalam Meningkatkan Living Values Siswa. Jurnal Pendidikan Sains Universitas Muhammadiah Semarang. Vol 2 (1).

Suraida. (2013). Pendidikan Berwawasan Lingkungan dalam Pembejaran Biologi. Jurnal Edu-Bio. 4, 1220. 
Talakua, C., Elly. S.S. (2020). Pengaruh Penggunaan Media Pembelajaran Biologi Berbasis Mobile Learning terhadap Minat dan Kemampuan Berpikir Kreatif Siswa SMA Kota Masohi. Jurnal Biodik, 6 (1), 46-57

Talakua, C., Maitimu, C.V. (2020). Efektifitas Media Pembelajaran Berbasis Smartphone Untuk Mengembangkan Sikap Peduli Lingkungan Peserta Didik. Jurnal Biodik, 6 (3), 392-401

Tinja, Y. Dkk. (2017). Pengembangan Bahan Ajar Tematik Berbasis Kearifan Lokal Sebagai Upaya Melestarikan Nilai Budaya pada Siswa Sekolah Dasar. Jurnal Pendidikan. 2(9), 1257-1261.

Utari, U., Degeng, I.N.S., \& Akbar, S. 2016. Pembelajaran tematik berbasis kearifan lokal di sekolah dasar dalam menghadapi Masyarakat Ekonomi Asean (MEA). Jurnal Teori dan Praksis Pembelajaran IPS, 1 (1), 39-44.

Wahyudin, U. (2015). The Quality of a 'Local Values Based' Fuctional Literacy Program: Its Contribution to the Improvement of the Learner's Basic Competencies. International Education Studies, 8 (2), $121-12$. 